УДК 697.12

\title{
ТЕМПЕРАТУРНО-ВОЛОГІСНИЙ СТАН СТІНОВОЇ КОНСТРУКЦІЇ 3 ШАРОМ УТЕПЛЮВАЧА В ЗИМОВИЙ ПЕРІОД РОКУ
}

Басок Б.І., член-кореспондент НАН України, Давиденко Б.В., докт. техн. наук, Тимощенко А.B., канд. техн. наук., Гончарук С.М., канд. техн. наук

Інститут технічної теплофізики НАН Украӥни, вул. Желябова, 2а, Київ, 03680, Украӥна

\begin{abstract}
За результатами експериментальних досліджень визначено залежність від погодних умов температурновологісного стану стінової конструкції 3 шаром утеплювача в зимовий період року. Результати експерименту порівнюються 3 результатами розрахунків за спрощеною моделлю тепло-вологопереносу через стінову багатошарову конструкцію.
\end{abstract}

По результатам экспериментальных исследований определена зависимость от погодных условий температурновлажностного состояния стеновой конструкции со слоем утеплителя в зимний период года. Результаты эксперимента сравниваются с результатами расчетов по упрощенной модели тепло-влагопереноса через стеновую многослойную конструкцию.
According to the results of experimental studies the dependence of temperature and humidity conditions of the wall structure with a layer of insulation in the winter season on the weather conditions is determined. The experimental results are compared with the results of calculations on a simplified model of heat and moisture transfer through multilayer wall structure.

Бібл. 1, рис. 8 .

Ключові слова: температурно-вологісний стан, стінова конструкція, утеплювач.

$j$, мг/(м² год) - густина потоку пари;

$m$, мг/(м год Па) - коефіцієнт паропроникності;

$P$, Па - парціальний тиск водяної пари;

$q, \mathrm{~B}$ - тепловий потік;

$\mathrm{R}, \mathrm{m}^{2} \mathrm{~K} / \mathrm{B} \mathrm{T}$ - термічний опір;

$t,{ }^{0} \mathrm{C}$ - температура;

$\beta$, мг/(м² год Па) - коефіцієнт масовіддачі;

$\delta$, м - товщина; $\lambda$,

$\lambda$, Вт/(м·К) -коефіцієнт теплопровідності;

$\tau$, год - час;

\section{Bcmyn}

Підвищення теплоізоляційної спроможності огороджувальних конструкцій будівель, що експлуатуються понад $30 . .40$ років, може здійснюватися шляхом їх термомодернізації. Головним чином, термомодернізація полгає в заміні старих вікон на сучасні енергоефективні віконні конструкції, а також в нанесенні на зовнішню поверхню будівлі шару теплоізоляційного покриття. Головна мета термомодернізації полягає в зменшенні тепловтрат через поверхню огорож. Водночас додатковий теплоізоляційний шар за рахунок підвищення температури несучої стінової конструкції сприяє $\varphi$ - відносна вологість повітря.

$$
\begin{aligned}
& \text { Нижні індекси: } \\
& \text { v-водяна пара; } \\
& a \text { - повітря; } \\
& \text { sat-насичена пара; } \\
& \text { б- бетон; } \\
& \text { у - утеплювач; } \\
& \text { вт - вата; } \\
& \text { зп - зовнішнє повітря. }
\end{aligned}
$$

зменшенню іiі вологовмісту, що забезпечує подовження строку експлуатації будівлі. Надлишкова волога, що проникає в капіляри пористих будівельних матеріалів, завдає їм руйнівної дії, знижуючи їх міцність.

Надлишкове зволоження стінової конструкції призводить також до зниження іiї термічного опору. Подовження ресурсу будівельних конструкцій та зниження рівнів тепловтрат через огорожі досягається шляхом запобігання процесам їх зволоження. Водяна пара, концентрація якої всередині приміщення в зимовий період року вища, ніж концентрація вологи в зовнішньому повітряному просторі, переноситься шляхом 
дифузії 3 приміщення назовні через будівельну конструкцію. У випадку переохолодження будівельної конструкції водяна пара може досягти стану насичення, що призводить до випадіння конденсату на поверхні або всередині огороджувальних конструкцій споруд, а при різкому похолоданні можлива кристалізація вологи та перетворення іiї в лід.

В даній роботі розглядаються результати експериментального дослідження температурновологісного стану тришарової стінової сандвічконструкції 3 додатковим шаром утеплюва- ча на іï зовнішній поверхні. За цими результатами визначається залежність температурнихта вологісних характеристик елементів даної стінової конструкції від погодних умов в зимовий період року.

\section{Експериментальний вимірювальний комплекс}

Для експериментального визначення залежностей від погодних умов температурновологісного стану будівельних конструкцій з шаром утеплювача застосовується вимірювальний комплекс, схему якого наведено на рис. 1.

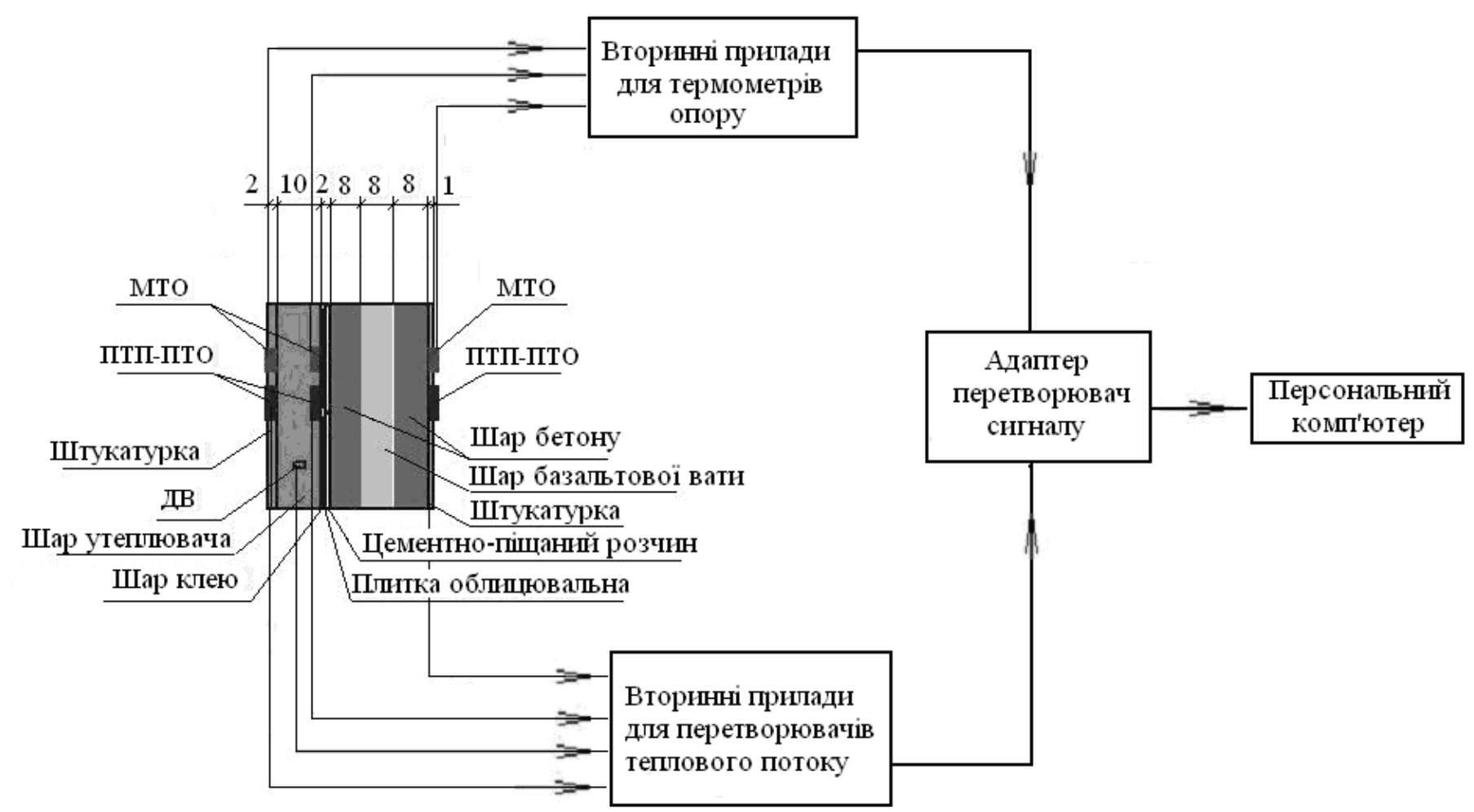

\section{Рис. 1. Схема експериментального вимірювального комплексу для дослідження тепловологопереносу через термомодернізовану стінову конструкцію.}

Як об'єкти дослідження використовувалися стінові конструкції (після їх часткової термомодернізаціï) корпусу №1 Інституту технічної теплофізики НАН України, що розташований на вул. Булаховського, 2. 3 використанням розробленого вимірювального комплексу в режимі реального часу визначалися густини теплових потоків на поверхнях шарів досліджуваних ділянок огороджувальних конструкцій, температурні показники їх поверхонь та відносна вологість повітря $\varphi$ всередині шарів утеплювачів. При цьому проводилася також безперервна фіксація температури та вологості повітряного середовища всередині приміщення, до якого відносилися досліджувані огороджувальні конструкції, та відповідні показники для зовнішнього повітряного середовища. Для кількісної оцінки тепловтрат через стінові конструкції застосовувалися перетворювачі теплового потоку 3 вмонтованими платиновими термометрами опору (ПТП ПТО). Для фіксації температурних показників використовували- 
ся також мідні термометри опору (МТО) типу ТСМ-205. Згадані пристрої встановлювалися на внутрішніх та зовнішніх поверхнях несучих стін (тобто між стіною та утеплювачем), а також на зовнішній поверхні утеплювача. Вони розташовувались практично на одній осі, перпендикулярній поверхні стіни.

Відносна вологість повітря всередині матеріалів утеплювачів вимірювалася за допомогою датчиків вологості (ДВ). Температура та вологість повітряного середовища всередині приміщення додатково фіксувалися за допомогою самозаписуючого термогігрометра testo $174 \mathrm{H}$. Bci згадані пристрої об'єднувались в загальну вимірювальну систему. Через вторинні пристрої i конвектор передачі даних сигнали 3 датчиків передавалися на персональний комп’ютер для їх подальшої статистичної обробки.

Досліджувана стінова конструкція представляє собою тришарову сандвіч-панель, яка складається 3 зовнішнього та внутрішнього шарів залізобетону, що мають однакову товщину $\delta_{\sigma, 1}=\delta_{\sigma, 2}=0,08$ м. Між шарами бетону знаходиться проміжок товщиною $\delta_{\text {вт }}=0,08 \mathrm{M}$, що заповнений мінеральною ватою. Загальна товщина несучої сандвіч-панелі складає 0,24 м. Термомодернізація цієї панелі виконувалася шляхом нанесення на іiі зовнішню поверхню шару утеплювача товщиною $\delta_{\text {y }}=0,10 \mathrm{M}$. Як варіанти утеплювачів застосовувалися плити з базальтової вати та 3 пінополістиролу (ППС-25).

\section{Аналіз результатів експериментальних досліджень}

Результати експериментальних досліджень температурних та вологісних характеристик стінових конструкцій, що утеплені плитами 3 базальтової вати, наведено на рис. 2, 3. Експериментальні дані відносяться до періоду 3 1 по 16 січня 2015 року.

На рис. 2 представлено залежності від часу температурних хараткеристик приміщення та стінової конструкції. Крива (1) характеризує зміну у часі температури повітря всередині приміщення. Крива (2) відтворює зміну у часі температури на внутрішній поверхні зовнішньої стіни. Залежність від часу температури зовнішньої поверхні несучої стінової панелі під утеплювачем описується кривою (3). Крива 4 описує зміну у часі температури зовнішньої поверхні утеплювача. Зміну у часі температури зовнішнього повітряного середовища хараткеризує крива 5. Як видно 3 рис. 2 (крива 5), 320 по 110 годину послідовних досліджень температура зовнішнього повітря була позитивною $\left(0{ }^{\circ} \mathrm{C}<t_{3}<+4,2{ }^{\circ} \mathrm{C}\right)$. Надалі температура зовнішнього повітря поступово знижується і досягає на 152 годину мінімального значення $t_{3}=-15{ }^{\circ} \mathrm{C}$. На часовому інтервалі від 152 до 192 години вимірювань температура зовіншнього повітря в денний час зростає до $-10{ }^{\circ} \mathrm{C}$ і знижується у нічний час до $-16{ }^{\circ} \mathrm{C}$. Після 192 години температура повітря починає збільшуватися і на 207 годину досягає значення 0 ' $\mathrm{C}$. Далі до 357 години вимірювань температура $t_{3 п}$ лишається позитивною. В денний час вона становить $+5{ }^{\circ} \mathrm{C} \ldots+7{ }^{\circ} \mathrm{C}$, а вночі знижується до $+1{ }^{\circ} \mathrm{C}$. Після 357 години температура повітря знову починає знижуватися і досягає негативного значення $\left(-3^{\circ} \mathrm{C}\right)$.

Температура на зовнішній поверхні утеплювача з базальтової вати змінюється майже сихронно $з$ температурою зовіншнього повітря. Різниця між цими значеннями температури змінюється в межах $\Delta t_{45}=t_{4}-t_{5}=-1,4{ }^{\circ} \mathrm{C} \ldots+1,1{ }^{\circ} \mathrm{C}$. Температура поверхні утеплювача у цілому вища, ніж температура зовнішнього повітря. Тільки у випадках інтенсивного зростання температури зовнішнього повітря, температура поверхні утеплювача, внаслідок теплової інерції стіни 3 утеплювачем, виявлялася нижчою, ніж температура повітря.

Температура внутрішньої поверхні утеплювача $t_{3}$, яка збігається $з$ температурою зовнішньої поверхні несучої стіни, виявляється суттєво вищою, ніж температура зовнішньої поверхні утеплювача $t_{4}$. Температура $t_{3}$ змінюється в значно меншому інтервалі, ніж $t_{4}$. Цей інтервал складає $+6 \ldots+13{ }^{\circ} \mathrm{C}$. Причому мінімального значення $t_{3}=+6{ }^{\circ} \mathrm{C}$ вона набуває на 174 годину вимірювань, тобто майже через 2,5 доби після початку зниження температури зовнішнього повітря. У цілому, зниження температури $t_{3}$ відбувається синхронно зі зниженням температури зовнішнього повітря. 


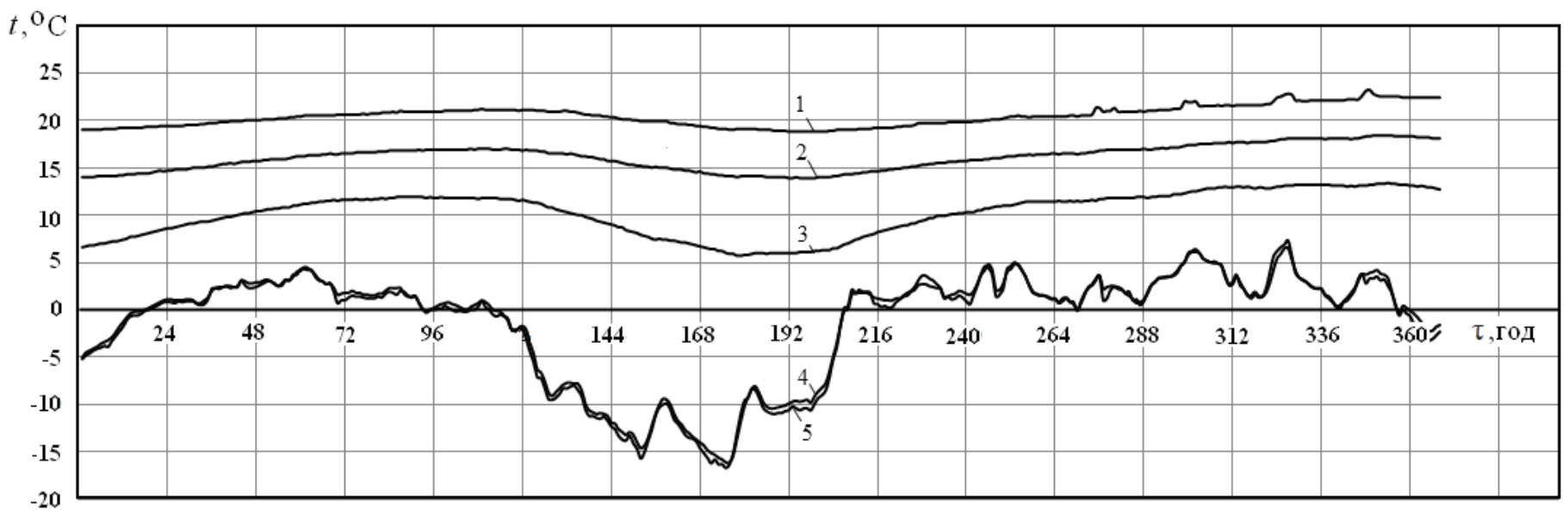

Рис. 2. Залежність від часу температури: 1 - повітря в приміщенні;

2 - внутрішньої поверхні стіни; 3 - під чаром утеплювача (базальтова вата);

4 - зовнішньої поверхні шару утеплювача; 5 - повітря у зовнішньому просторі.

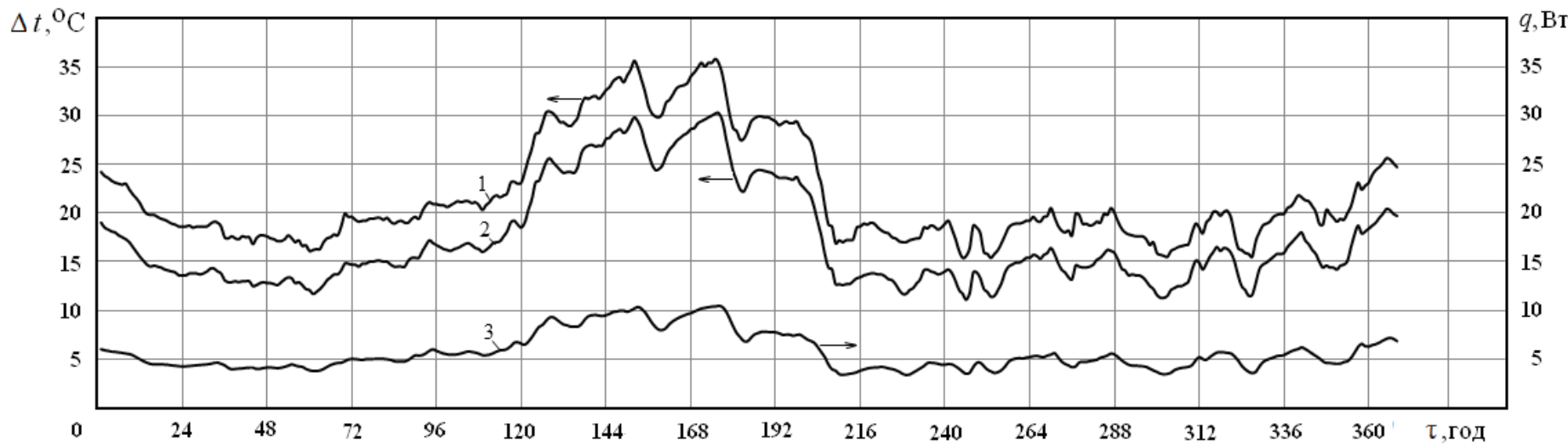

Рис. 3. Залежність від часу:

1 - різниці міэс температурами повітря в приміценні та повітря назовні;

2 - різниці мію температурами внутрішньої поверхні стіни та зовнішньої поверхні утеплювача;

3 - дустини теплового потоку під утеплювачем (базальтова вата), а саме в плоцині зовнішньої поверхні несучої стіни, тобто між несучою стіною та утеплювачем.

Температура внутрішньої поверхні стіни $t_{2}$ змінюється у межах $+14 . .+17{ }^{\circ} \mathrm{C}$. Мінімального значення вона набуває на 196 годину вимірювань, а далі починає збільшуватися. Її значення виявляються стабільнішими, ніж значення температури $t_{3}$. Температура повітря всередині приміщення $t_{1}$ також достатньо стабільна і змінюється у межах $+18 \ldots+22{ }^{\circ} \mathrm{C}$. Майже незмінною виявляється також різниця між значеннями температури повітря в приміщенні і температури внутрішньої поверхні стіни: $\Delta t_{12}=t_{1}-t_{2}=4 \ldots 5^{\circ} \mathrm{C}$.

Певний інтерес представляють також залежності від часу температурного напору між повітрям всередині приміщення та повітрям назовні $\Delta t_{15}=t_{1}-t_{5}$, а також температурного напору $\Delta t_{24} \stackrel{=}{=} t_{2}-t_{4}$ між внутрішньою поверхнею несучої стіни та зовнішньою поверхнею утеплювача. Ці залежності наведено на рис. 3 (криві 1 та 2 відповідно). Як видно з рис. 3, температурний напір $\Delta t_{15}$ набуває максимального значення $+35^{\circ} \mathrm{C}$ тоді, коли найсуттєвіше знижується температура зовнішнього повітря, тобто на 175 годину вимірювань, на яку припадає найменша температура зовнішнього повітря $t_{5}=-16,7^{\circ} \mathrm{C}$. Температурний напір $\Delta t_{24}$ набуває максимального значення також на 175 годину вимірювань і складає 
$\Delta t_{2-4}=30,2{ }^{\circ} \mathrm{C}$.

Кривою 3 на рис. 3 відображено залежності від часу густини теплового потоку $q$, що вимірюється між зовнішньою поверхнею несучої стіни та внутрішньою поверхнею утеплювача. Ця густина теплового потоку змінюється в межах 3,4 Вт/м²..10,4 Вт/м². Максимального значення зазначений тепловий потік, що характеризує теплові втрати приміщення, набуває при мінімальному значенні температури повітря назовні, а мінімального - коли темпера- тура зовнішнього повітря максимальна. Тобто максимуми і мінімуми густини теплового потоку збігаються у часі з максимумами і мінімумами температурних напорів $\Delta t_{15}$ та $\Delta t_{24}$.

Залежність густини теплового потоку $q$ від температурного напору $\Delta t_{24}$ наведено на рис. 4. На цьому ж рисунку відображено лінію, що апроксимує цю залежність. За котангенсом кута нахилу цієї лінії визначається термічний опір несучої стіни з утеплювачем (базальтова вата): $R=3,1 \mathrm{M}^{2} \mathrm{~K} / \mathrm{BT}$.

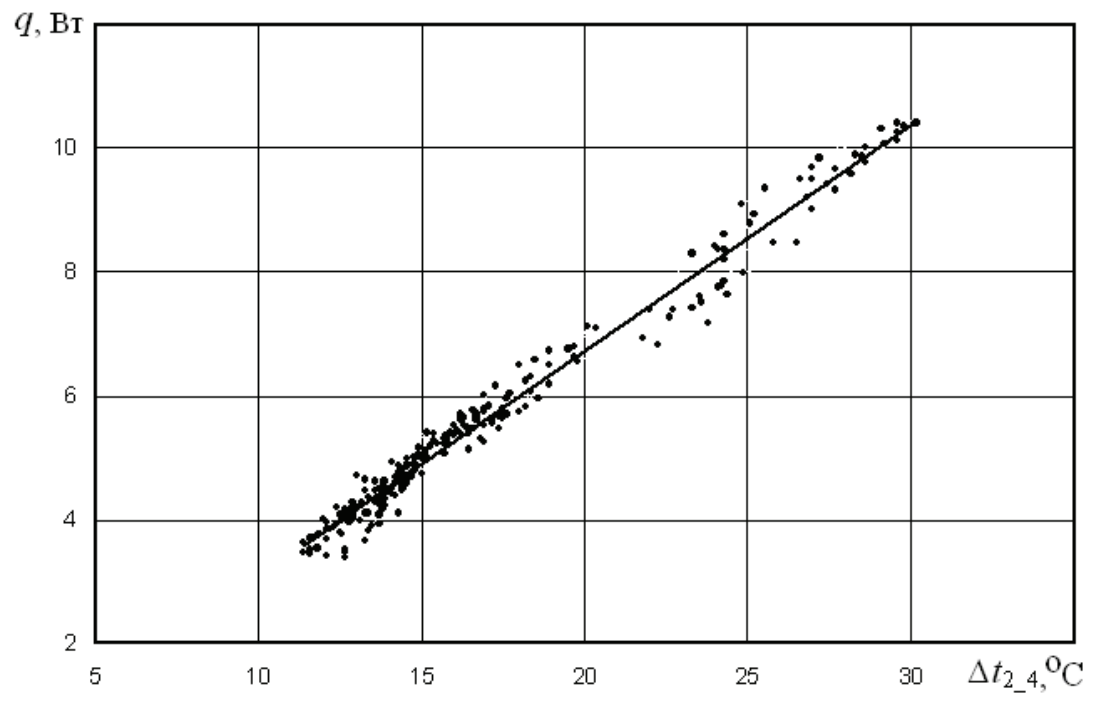

Рис. 4. Залежність густини теплового потоку під утеплювачем (базальтова вата) від різниці міжс температурами внутрішньої поверхні стіни та зовнішньої поверхні утеплювача.

Залежності відносної вологості повітря всередині приміщення, повітря всередині утеплювача (базальтова вата) та зовнішнього повітря наведено на рис. 5.3 кривої 3 на цьому рисунку видно, що відносна вологість зовнішнього повітря за період досліджень суттєво змінювалася: від $\varphi=60 \%$ до $\varphi=100 \%$. При цьому суттєва зміна відносної вологості зовнішнього повітря відбувалась навіть протягом однієї доби. Можна зазначити, що найвищих значень відносна вологість набувала при найвищих значеннях температури зовнішнього повітря, а найнижчих - при мінімальних температурах. В цих умовах відносна вологість внутрішнього повітряного середовища лишалася майже незмінною: $\varphi=29$ \%...32 \%. Що стосується відносної вологості пароповітряного середовища всередині базальтової вати, то вона змінювалася в діапазоні $\varphi=68$ \%...84\%. Тобто їі значення знаходилися між значеннями відносної вологості повітря всередині приміщення та повітря назовні.

За величинами $\varphi$ визначаються величини парціального тиску водяної пари $P_{v}$

$$
P_{v}=\varphi P_{v}(T)
$$

Залежність від ${ }^{v}$ часу ${ }^{v}$ парціальних тисків водяної пари в повітряному середовищі приміщення, всередині утеплювача (базальтова вата) та в зовнішньому повітрі наведено на рис. 6. 3 кривої 3 на цьому рисунку видно, що парціальний тиск водяної пари у зовнішньому повітрі змінюється за період досліджень від $P_{v}=112$ Па до $P_{v}=888$ Па. Найвищих значень парціальний тиск водяної пари в зовнішньому повітрі набуває на 254 годину вимірювань, коли температура зовнішнього повітря складає $t_{5}=4,6^{\circ} \mathrm{C}$, а відносна вологість наближається до 
100 \%. Треба зазначити, що такий максимально високий тиск водяної пари в зовнішньому повітрі, що навіть перевищував парціальний тиск в приміщенні та в утеплювачі, тримався лише протягом $1 \ldots 2$ годин. Через п’ять годин він знизив- ся до $P=600$ Па і надалі змінювався в діапазоні $P_{v}=500 \ldots 700$ Па. Найнижчих значень парціальний тиск водяної пари назовні досягав на 171 годину, коли температура зовнішнього повітря складала $t_{5}=-16{ }^{\circ} \mathrm{C}$, а відносна вологість була $65 \%$.

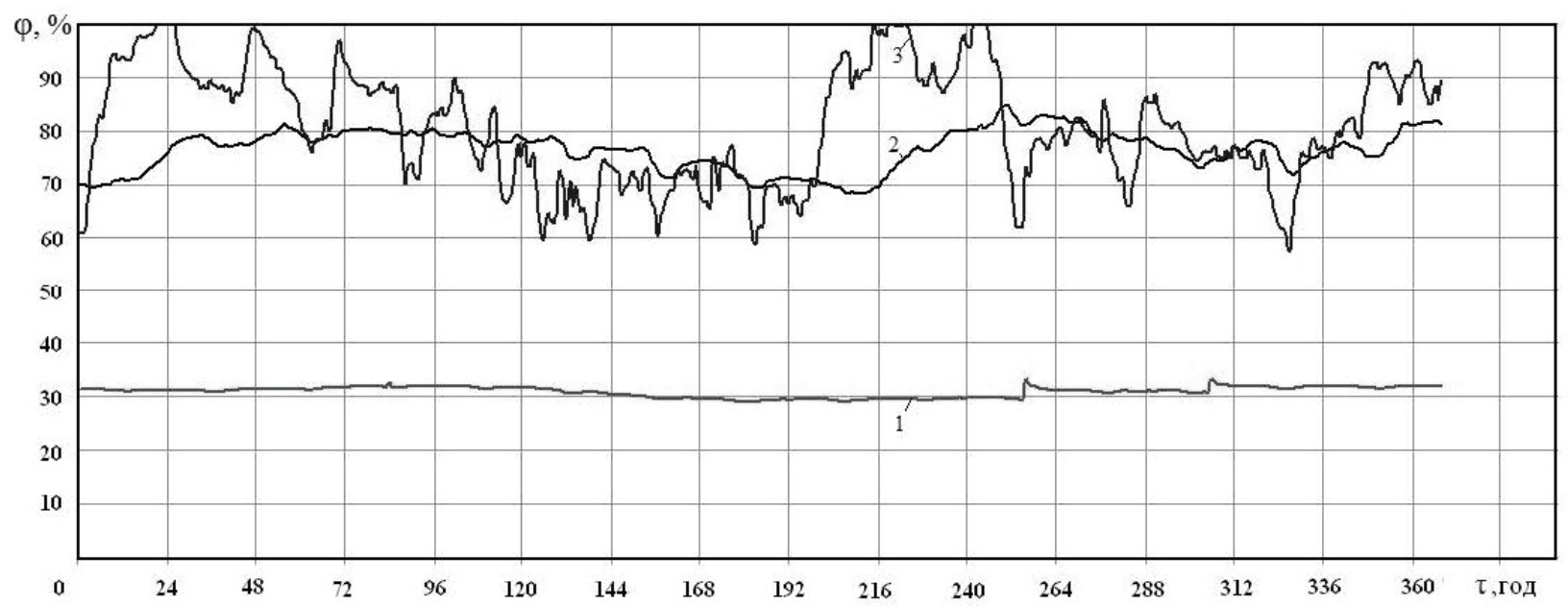

Рис. 5. Залежність від часу відносної вологості:

1 - повітря в приміщенні; 2 - пароповітряної суміші всередині шару утеплювача (базальтова вата); 3 - повітря у зовнішньому просторі.

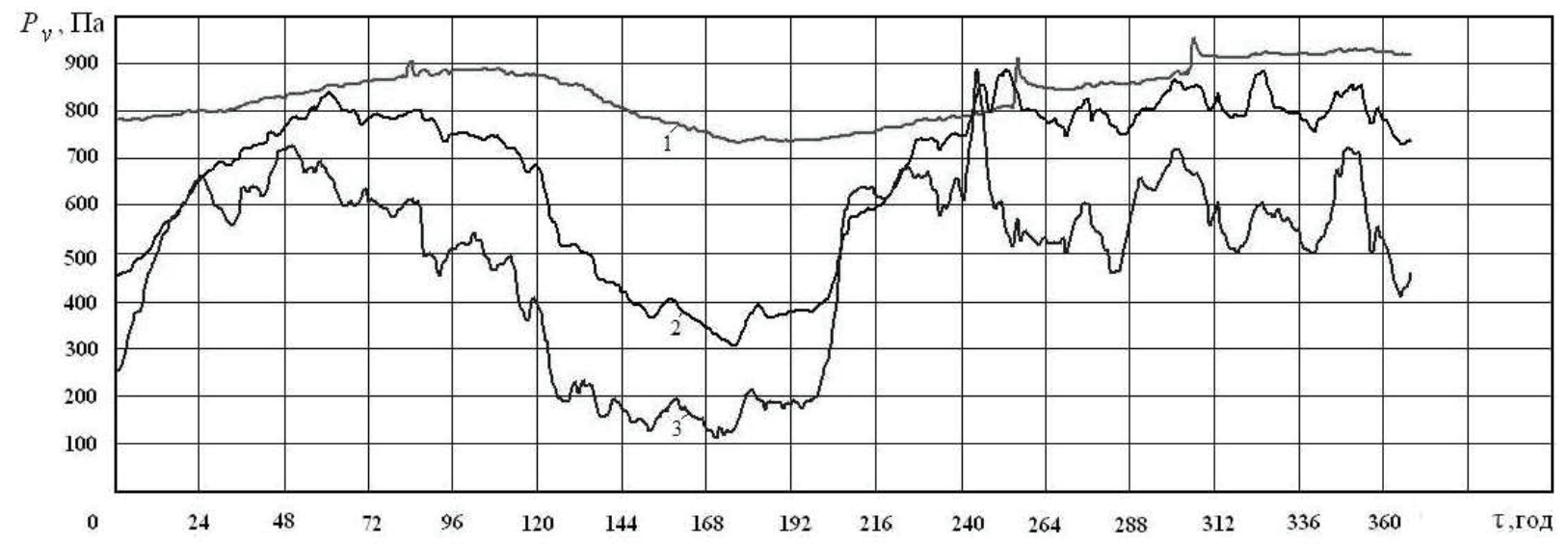

Рис. 6. Залежність від часу парціального тиску водяної пари:

1 - в повітрі приміщення; 2 - в пароповітряній суміші всередині шару утеплювача (базальтова вата); 3 -у зовнішньому повітрі.

За досліджуваний період парціальний тиск водяної пари всередині приміщення змінювався в діапазоні $P_{v}=732 \ldots 948$ Па (крива 1, рис. 6), тобто діапазон зміни парціального тиску водяної пари всередині приміщення значно нижчий, ніж повітря назовні, що пояснюється більш стабільними температурними та вологісними умовами всередині приміщення. Парціальний тиск водяної пари всередині базальтової вати в даних умовах змінювався в діапазоні $P_{v}=306 . .886$ Па (крива 2, рис. 6). Тобто його значення знаходилися між значеннями парціального тиску водяної пари всередині приміщення та у зовнішньому повітрі. При цьому ці значення протягом досліджуваного періоду наближалися як до парціального тиску водяної пари всередині 
приміщення, так і до парціального тиску пари у зовнішньому повітрі.

Як видно 3 наведених експериментальних результатів, відносна вологість повітря назовні суттєво вища за відносну вологість повітря всередині приміщення. Але при цьому парціальний тиск водяної пари всередині приміщення виявляється вищим (за винятком невеликого проміжку часу), ніж парціальний тиск водяної пари у зовнішньому повітрі. Це свідчить про наявність процесу переносу пари 3 приміщення назовні в зимовий період.

Дифузійний потік водяної пари через капілярно-пористий матеріал зазвичай розраховується за виразом

$$
j_{v a}=-m \cdot \operatorname{grad}\left(P_{v}\right) .
$$

На основі наведеного виразу складається спрощене рівняння для одномірного потоку водяної пари через багатошарову будівельну конструкцію, що розглядається:

$$
j_{v a}=\frac{\frac{1}{\beta_{\mathrm{B}}}+\frac{\delta_{\sigma, 1}}{\mathrm{~m}_{\sigma}}+\frac{\delta_{\text {в }}}{\mathrm{m}_{\text {вт }}}+\frac{\delta_{\sigma, 2}}{\mathrm{~m}_{\sigma}}+\frac{\delta_{\mathrm{y}}}{\mathrm{m}_{\mathrm{y}}}+\frac{1}{\beta_{3}}}{,}
$$

де $P_{v, \text { в }}$ та $P_{v, 3}$ - парціальні тиски водяної пари в приміщенні та у зовнішньому просторі відповідно; $\beta_{\text {в }} \beta_{3}-$ коефіцієнти масовіддачі на внутрішній та на зовнішній поверхні багатошарової стіни відповідно; $m_{\tilde{\sigma}} ; m_{\text {вт }} m_{\text {у }}-$ коефіцієнти паропроникності бетону, мінеральної вати та матеріалу утеплювача відповідно.

За одномірною стаціонарною моделлю приймається, що потік пари проходить через всі шари стінової конструкції, не змінюючи свого значення. Тому його можна також представити у вигляді:

$$
j_{v a}=\frac{P_{v, \mathrm{~B}}-P_{v, \mathrm{y}}}{\frac{1}{\beta_{\text {в }}}+\frac{\delta_{\sigma, 1}}{\mathrm{~m}_{\sigma}}+\frac{\delta_{\text {вт }}}{\mathrm{m}_{\text {вт }}}+\frac{\delta_{\sigma, 2}}{\mathrm{~m}_{\sigma}}+\frac{0,5 \delta_{\mathrm{y}}}{\mathrm{m}_{\mathrm{y}}}}
$$

де $P_{v, \mathrm{y}}$ - парціальний тиск водяної пари всередині утеплювача.

Прирівнюючи ці два вирази для потоку водяної пари, можна наближено розрахувати значення парціального тиску водяної пари всередині утеплювача $P_{v, \mathrm{y}}$ :

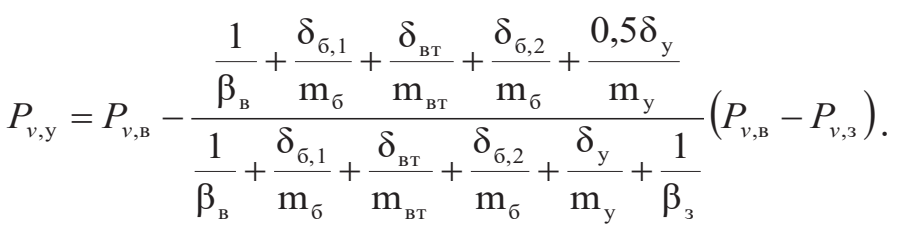

Для розрахунків парціальних тисків водяної пари всередині утеплювача приймається (згідно 3 [1]), що $m_{\sigma}=0,03$ мг/(м год Па); $m_{\text {вт }}=0,53 \mathrm{мг} /\left(\right.$ м год Па); $m_{\mathrm{y}}=0,53 \mathrm{мг} /($ м год Па $)-$ для базальтової вати. Коефіцієнти масовіддачі $\beta$; $\beta_{3}$ на внутрішній та на зовнішній поверхнях багатошарової стіни розраховуються за аналогією між тепловіддачею та масовіддачею.

Результати порівняння розрахункових залежностей від часу парціальних тисків водяної пари всередині утеплювача 3 базальтової вати 3 залежностями, що одержані в експерименті (рис. 6), наведено на рис. 7. Як видно з рисунку, результати експериментальних та розрахункових досліджень якісно подібні, але чисельні значення парціального тиску, що знайдені 3 розрахунків, виявляються нижчими, ніж ті, що одержані 3 експерименту. Це пояснюється як наближеним характером розрахункової моделі, так і можливою невідповідністю застосованих коефіцієнтів паропроникності реальним характеристикам пористих матеріалів у досліджуваній будівельній конструкції.

Експериментальні дослідження виконувалися також для подібної стінової конструкції, утеплювачем якої був пінополістирол ППС-25, для якого $m_{\mathrm{y}}=0,05 \mathrm{мг/(м \cdot год \cdot Па)}$ [1]. Порівняння результатів експериментального визначення парціального тиску водяної пари всередині утеплювача ППС-25 3 розрахунковими результатами наведено на рис. 8. Як і у випадку утеплювача з базальтової вати, експериментально визначені величини парціального тиску всередині ППС-25 (крива 2) виявилися вищими, ніж аналогічні значення, що одержані за спрощеною розрахунковою моделлю (крива 1). Водночас треба зазначити, що розбіжність між їх чисельними значеннями у випадку утеплювача ППС-25 виявляється менш суттєвою, ніж у випадку утеплювача з базальтової вати. 


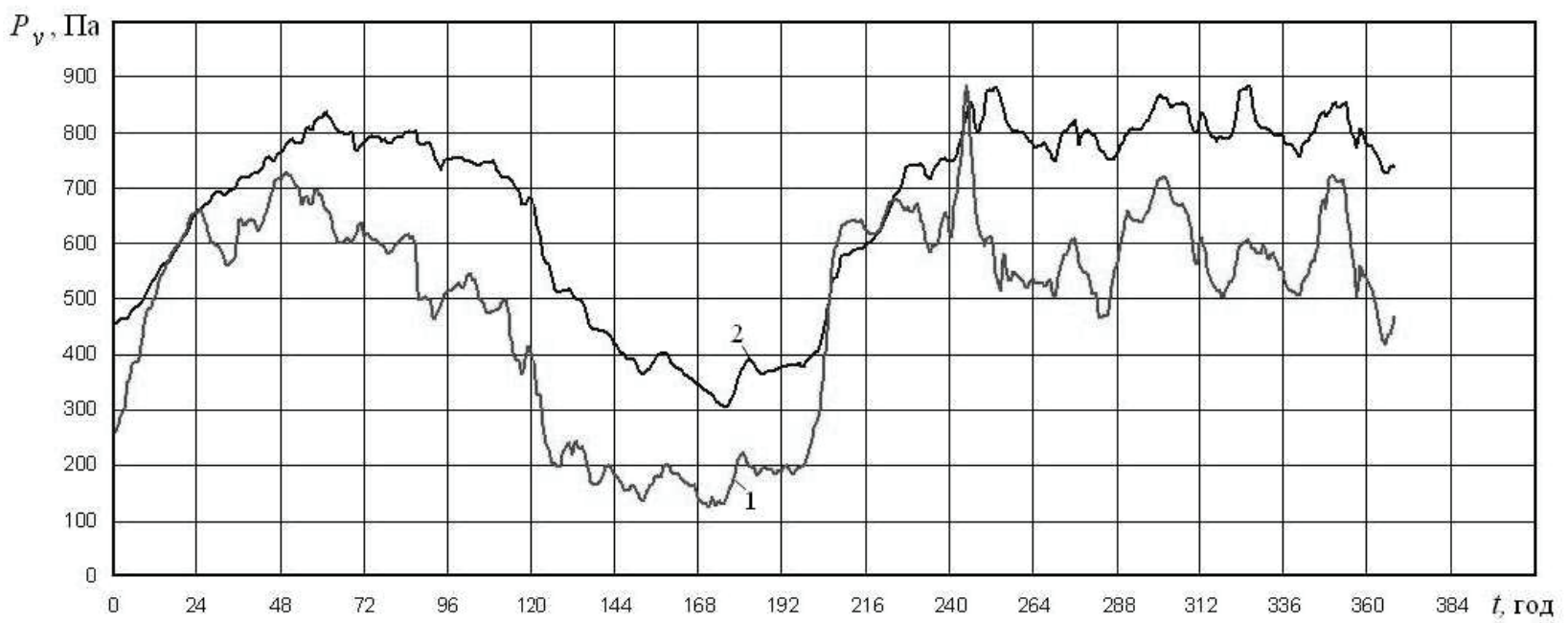

Рис. 7. Залежність від часу парціального тиску водяної пари в утеплювачі з базальтової вати: 1 -результати розрахунку; 2 - результати експерименту.

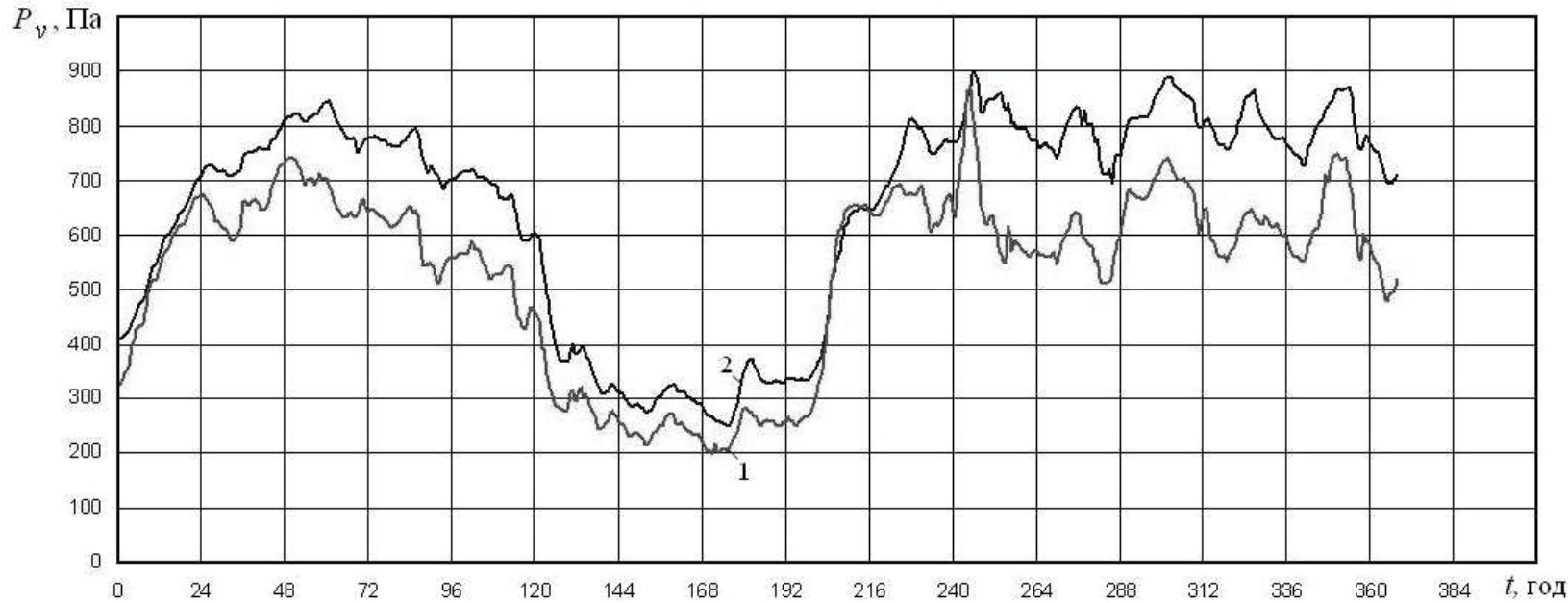

Рис. 8. Залежність від часу парціального тиску водяної пари в утеплювачі ППС-25: 1 -результати розрахунку; 2 - результати експерименту.

\section{Висновки}

1. 3 результатів експериментальних досліджень випливає, що додатковий шар утеплювача на зовнішній поверхні несучої стінової конструкції сприяє як підвищенню температури цієї поверхні, так і зменшенню діапазону їі зміни при суттєвій зміні температури навколишнього середовища. Температура на зовнішній поверхні утеплювача не суттєво відрізняється від температури у зовнішньому повітрі.

2. Відносна вологість повітря назовні суттєво вища, ніж відносна вологість повітря всередині приміщення. Але парціальний тиск водяної пари всередині приміщення виявляється вищим, ніж парціальний тиск пари у зовнішньому повітрі. Внаслідок цього водяна пара в зимовий період року переноситься через стінову конструкцію 3 приміщення назовні. Парціальний тиск пари всередині утеплювача нижчий, ніж парціальний тиск пари у приміщенні, але вищий, ніж парціальний тиск пари назовні.

3. Одержані за наближеною моделлю тепломасопереносу розрахункові дані якісно 
відтворюють реальну зміну у часі парціального тиску пари всередині утеплювача. Розрахункові значення парціального тиску пари виявляються нижчими, ніж ті, що отримані з експерименту.

\section{ЛІТЕРАТУРА}

1. ДБН В.2.6-31:2006. Конструкції будівель i споруд. Теплова ізоляція будівель. Мінбуд України.- Київ.-2006. - 70 с.

\section{TEMPERATURE AND HUMIDITY CONDITIONS OF WALL CONSTRUCTION WITH LAYER OF INSULATION IN THE WINTER PERIOD}

\section{Basok B.I., Davydenko B.V., Timoshchenko A.V., Goncharuk S.M.}

Institute of Engineering Thermophysics of the National Academy of Sciences of Ukraine, vul. Zhelyabova, 2a, Kyiv-57, 03057, Ukraine

By the results of experimental studies the dependence of temperature and humidity condition of a threelayer wall construction with a layer of insulation on the outer surface on the weather conditions during the winter season was determined. It is shown that the additional layer of insulation on the outer surface of the base wall increases the temperature of this surface. This also reduces a range of variation the surface temperature at the substantial changes in ambient temperature. The partial pressure of water vapor inside the room exceeds the vapor partial pressure in the environment, except when the relative humidity of the outside air is close to $100 \%$. The partial vapor pressure inside the layer of insulation is lower than the partial pressure in the room, but higher than the partial vapor pressure in the environment.

References 1, figures 8 .

Key words: temperature and humidity condition, wall construction, insulation

1. DBN V.2.6-31:2006. Konstruktsiyi budivel' i sporud. Teplova izolyatsiya budivel'. Minbud Ukrayiny. - Kyiv.-2006.- 70 s. (Ukr).

Получено 28.04.2016 Received 28.04.2016 